\title{
Carbon and Metal Transformations Near the Continent-Ocean Margin Quantified with the ZAPS Instrument Package
}

\author{
Gary Klinkhammer \\ College of Oceanic and Atmospheric Sciences \\ Oregon State University \\ Ocean Admin Bldg 104 \\ Corvallis OR 97331-5503 \\ phone: (541) 737-5209 \\ fax: (541) 737-2064 \\ email: gklinkhammer@oce.orst.edu \\ Award No. N00014-92J1299 \\ http://www.oce.orst.edu/faculty/klinkhammer.html
}

\section{LONG TERM GOAL}

We use innovative experimental approaches to measure the extent of biogeochemical interaction driven by the input of terrestrial organic carbon to the coastal oceans. The evolution of organic carbon from continents to oceans is not well understood. Remineralization of this carbon plays an unknown but apparently important role in stimulating productivity. This process and associated phenomena also affect ocean color, turbidity, and elemental recycling. Our long-range goal is to quantify these processes in space and time.

\section{OBJECTIVES}

Quantification of biogeochemical change at the land-ocean boundary requires that we gain better insights into fundamental relationships between organic carbon and other parameters, such as total suspended particulate matter and dissolved metals. Several interrelated objectives link the processes affecting organic carbon to our ability to measure physical and chemical gradients in the water column.

- development of technology to make it possible to collect high resolution data sets of trace substances in situ and in real time

- delineation of mixing trends for particles, dissolved organic carbon, and metals to ground truth sensors and to identify the most labile parts of the system

- quantification of remineralization rates by detailed sampling and controlled in situ experiments

- extrapolation of observations to a representative group of oceanic settings.

These objectives provide a framework for developing and applying technology to follow the evolution of terrestrial carbon from rivers, through estuaries, and into the coastal ocean.

\section{APPROACH}

Our objectives require technology to measure optical and chemical properties at high resolution. In the early stages of our project we developed a system of instruments capable of recording critical parameters associated with the cycling of metals and organic carbon. This package produces highresolution distributions of light level, chlorophyll, dissolved terrestrial humic material, dissolved marine proteins, dissolved manganese and suspended particulate matter, as well as temperature, depth, and conductivity. We call this package the ZAPS instrument package. The centerpiece of this package is the ZAPS (zero angle photon spectrometer) fiber optic spectrometer (Klinkhammer, 1994). ZAPS 


\section{Report Documentation Page}

Form Approved

OMB No. 0704-0188

Public reporting burden for the collection of information is estimated to average 1 hour per response, including the time for reviewing instructions, searching existing data sources, gathering and maintaining the data needed, and completing and reviewing the collection of information. Send comments regarding this burden estimate or any other aspect of this collection of information,

including suggestions for reducing this burden, to Washington Headquarters Services, Directorate for Information Operations and Reports, 1215 Jefferson Davis Highway, Suite 1204, Arlington

VA 22202-4302. Respondents should be aware that notwithstanding any other provision of law, no person shall be subject to a penalty for failing to comply with a collection of information if it

does not display a currently valid OMB control number.

1. REPORT DATE

30 SEP 1999

4. TITLE AND SUBTITLE

Carbon and Metal Transformations Near the Continent-Ocean Margin Quantified with the ZAPS Instrument Package

6. $\operatorname{AUTHOR}(\mathrm{S})$

7. PERFORMING ORGANIZATION NAME(S) AND ADDRESS(ES)

Oregon State University,College of Oceanic and Atmospheric Sciences,104 Oceanography Admin Bldg,Corvallis,OR,97331

9. SPONSORING/MONITORING AGENCY NAME(S) AND ADDRESS(ES)

12. DISTRIBUTION/AVAILABILITY STATEMENT

Approved for public release; distribution unlimited

13. SUPPLEMENTARY NOTES

14. ABSTRACT

15. SUBJECT TERMS

16. SECURITY CLASSIFICATION OF:

a. REPORT

unclassified b. ABSTRACT

unclassified c. THIS PAGE

unclassified
17. LIMITATION OF ABSTRACT

Same as

Report (SAR)
3. DATES COVERED

00-00-1999 to 00-00-1999

5a. CONTRACT NUMBER

5b. GRANT NUMBER

5c. PROGRAM ELEMENT NUMBER

5d. PROJECT NUMBER

5e. TASK NUMBER

5f. WORK UNIT NUMBER

8. PERFORMING ORGANIZATION

REPORT NUMBER

10. SPONSOR/MONITOR'S ACRONYM(S)

11. SPONSOR/MONITOR'S REPORT $\operatorname{NUMBER}(S)$ 
makes it possible to examine the behavior of terrestrial organic carbon as it mixes into the coastal ocean and better understand between organic matter and metals.

\section{WORK COMPLETED}

We carried out a 6 day cruise to the Columbia River estuary in October 1999. Our data support the idea that microbial life has evolved to take advantage of sunlight and oxide coatings in attacking organic matter in the water column. We have known for some time (Froelich et al., 1979) that microbes use a series of oxidants to degrade organic matter in sediments. Microbes use several oxidants to do this work: oxygen-nitrate-manganese oxide-iron oxide. The most sensitive indicators of microbial activity are dissolved manganese and dissolved iron because of their relatively low concentrations in unaffected seawater. Microbial degradation is pervasive in sediments and can degrade as much as $90 \%$ of the particulate organic carbon from a large system like the Amazon River (Aller et al., 1996). Our data indicate that these processes are not restricted to sediments or particulate organic carbon but are also active in the estuary turbidity maximum (ETM).

We found a pervasive maximum in dissolved Mn between 8 and $10 \mathrm{~m}$ throughout the estuary. The Mn anomaly is sometimes associated with the top of the ETM (SPM $>50 \mathrm{mg} / \mathrm{L})$, but persists at lower turbidities. The Mn anomalies cut across all salinity, temperature, and density gradients and seem to be focused on the uppermost part of the ETM.

\section{RESULTS}

The anomalously high levels of dissolved Mn we observed could result from either of two processes. (i) Dissolved Mn might be imported from the large mudflats that dominate the lower estuary or (ii) dissolved Mn might be produced by in situ reduction of oxides in the water column. Either one of these sources would require microbial mediation.

One striking characteristic of Mn anomalies in the Columbia is that the depth of the maximum varies by only a couple of meters. As we pointed out previously, these anomalies cut across all salt, temperature, and density gradients. So what is so special about 8 to $10 \mathrm{~m}$ ? Last year we made the important observation that these anomalies always occur at the base of the photic zone. This observation suggests that the Mn reduction we observe may be part a light-sensitive process linked with microbial reduction. This explanation fits with previous observations of high bacterial abundances (Baross, 1995, Crump and Baross, 1996) and elevated Mn/Al ratios (Prahl et al., 1997) for particulate matter in the ETM.

Other workers have demonstrated in laboratory experiments that certain bacteria oxidize humic substances using reduction of their manganese oxide coatings (Sunda and Kieber, 1994). Our observations are the first evidence that this process is prevalent in nature. The fact that this process can maintain such intense dissolved Mn maxima in a dynamic environment like the Columbia suggests that the oxide reduction is quite vigorous as it must generate enough material to maintain a generous supply of dissolved Mn against turbulent mixing. The residence time of water in the estuary is only 12 days.

\section{TECHNOLOGY}


We designed and constructed the first underwater fiber optic spectrometers (Klinkhammer, 1994). We developed flow-through (FT) chemical sensors based on this technology. We also developed new immobilization techniques that are an integral part of FT analyzers. FT sensors are a powerful alternative to the popular FIA-type (flow injection) techniques. Flow-through sensors offer the advantage of faster updating and are thus more suitable for profiling applications or work in dynamic chemical environments like estuaries. FT analyzers are based on fiber optic technology and lend themselves to current ideas about deep-sea observatories. FT analyzers are versatile light-processing systems capable of exploiting several chemical techniques including fluorescence and light absorption.

\section{ZAPS Spectrometers}

fluorescence of humic material

ZAPS is a true in situ fluorometer. This means that increasing incident radiation and detector amplification improves fluorescence detection over a wide range. This is not true for standard celltype instruments where the background from scattering increases proportionately with the signal. Fluorescence data produced with this instrument is reproducible at the $\pm 0.8 \%$ level (Klinkhammer et al., 1999). Fluorescence from ZAPS has been shown to be remarkably linear when plotted against DOC in regions dominated by terrestrial carbon, like the western Arctic (Guay et al., 1999). fluorescence of proteinaceous carbon

ZAPS is very effective in the deep UV making it possible to excite most fluorescent organic compounds. This fluorescence pool is distinctly different than humic material. Recent developments in UV detectors will allow ZAPS output to be captured as a spectrum.

\section{manganese}

The ZAPS analyzer is the first system to measure manganese at its lowest oceanic level $(0.1 \mathrm{nM})$. Sample in the flow-cell is renewed every few seconds allowing the system to detect small signals while profiling in dynamic settings, like those found in the Columbia. We now have data from showing the relationship Mn and coastal water masses at high resolution for the first time.

nitrate

There has been renewed interest in the detection of nitrate by UV absorption (Finch et al., 1998). Recent improvements in photonic components make this measurement feasible by in situ detection for the first time. We were able to produce nitrate profiles on recent cruises to Antarctica and the Oregon coast. Things become more complicated in estuaries because there is interference from humic material and salinity. We used results from the Columbia to develop correction algorithms.

\section{ZAPS Instrument Package}

We built up a sophisticated instrument package around fiber optic spectrometers. The package produces an extensive view of the biogeochemical fabric of the water column in real time. This package serves as an experimental platform on which to build new chemistries and test new sensors against a backdrop of full chemical characterization.

\section{RELATED PROJECTS}

ZAPS technology has found application in a wide range of projects. We used our sled this year to explore the Bransfield Strait, Antarctica for hydrothermal vent sites (NSF -Office of Polar Programs; OPP-9725872). We used the real time sensing capability to locate a vent field and map hydrothermal signals at several locations.

We used the ZAPS package to investigate water column chemistry above an emerging hydrate site as part of the TECFLUX Program (NSF -Chem. Ocean.; OCE-9811471). We produced hydrography and 
incorporated a methane sensor into the package. We were able to map dissolved methane plumes above the accretionary ridges that make up the TECFLUX site using this device. The detection limit was better than 105 ppm.

We are working with K. Falkner to develop additional methods so we can broaden the use of ZAPS as a chemical analyzer. Our initial goal is to build a barium sensor that we will use to track the influence of river water in the Arctic. Ba turned out to be a perfect compliment to humic carbon in the SCICEX Program (Guay et al., 1999).

\section{REFERENCES}

Aller R.C., Blair N. E., Xia Q., and Rude P.D. (1996) Remoneralization rates, recycling, and storage of carbon in Amazon Shelf sediments. Con. Shelf. Res. 16, 753-786.

Baross J.A., Crump B and Simenstad C.A. (1994) Elevated 'microbial loop' activities in the Columbia River estuary turbidity maximum. In Changing Particle Fluxes in Estuaries: Implications From Science to Management (Dyer K. and Orth R., eds). ECA22/ERF Symposium. Olsen and Olsen Press, Friedensborg, 459-464.

Crump B.C and Baross J.A. (1996) Particle-attached bacteria and heterotrophic plankton associated with the Columbia River estuarine turbidity maxima, Mar. Ecol. Prog. Ser., 138, 265-273.

Froelich P.N., G.P. Klinkhammer, M.L. Bender, G.R. Heath, N. Luedtke, D. Cullen, P. Daulphin, D. Hammond, B. Hartman and V. Maynard (1979) Early Oxidation of organic matter in pelagic sediments of the Eastern Equatorial Atlantic: Suboxic diagenesis, Geochim. Cosmochim. Acta. 43, 1075-1090.

Finch M.S., Hydes D.J., Clayson C.H., Weigl B., Dakin J. and Gwilliam P. (1998) A low power ultra violet spectrophotometer for measurement of nitrate in seawater: introduction, calibration and initial sea trials, Anal. Chim. Acta, 377, 167-177.

Guay C.K., Klinkhammer G.P., Falkner K.Kenison and Benner R., Black B., Coble P.G., and Bussell F.J. (1999) High-resolution measurements of dissolved organic carbon in the Arctic Ocean by in-situ fiber-optic spectrometry, Geophys. Res. Lett., 26, 1007-1010.

Klinkhammer G.P. (1994) Spectrophotometer for Chemical Analyses of Fluids, US Patent 5,304,492.

Klinkhammer G.P., McManus J., Colbert D. and Rudnicki M.D., (1999) Behavior of terrestrial dissolved organic matter at the continent-ocean boundary from high-resolution distributions, Geochim. Cosmochim. Acta (accepted).

Prahl F.G., Small L.F. and Eversmeyer B. (1997) Biogeochemical characterization of suspended particulate mater in the Columbia River estuary. Mar. Ecol. Prog. Ser., 160, 173-184.

Sunda W.G. and Kieber D.J (1994) Oxidation of humic substances by manganese oxides yields lowmolecular-weight organic substrates, Nature, 367, 62-64.

\section{PUBLICATIONS}

German C.R., Rudnicki M.D. and Klinkhammer G.P., (1999) A segment-scale survey of the Broken Spur hydrothermal plume, Deep-Sea Res. I, 46, 701-714. 
Guay C.K., Klinkhammer G.P., Falkner K.Kenison and Benner R., Black B., Coble P.G., and Bussell F.J. (1999) High-resolution measurements of dissolved organic carbon in the Arctic Ocean by in-situ fiber-optic spectrometry, Geophys. Res. Lett., 26, 1007-1010.

McManus J, Berelson W.M., Hammond D.E. and Klinkhammer G.P., (1999) Barium cycling in the North Pacific: Implications for the utility of $\mathrm{Ba}$ as a paleoproductivity and a paleoalkalinity proxy, Paleo., 14, 53-61.

McManus J., Berelson W.M., Klinkhammer G.P., Johnson K.S., Coale K.H., Anderson, R., Kumar N., Burdige D.J., Hammond D.E., Brumsack H.J., and McCorkle D.C. (1999) Geochemistry of barium in marine sediments: Implications for its use as a paleoproxy, Geochim. Cosmochim. Acta., 62, 34533473.

Klinkhammer G.P., McManus J., Colbert D. and Rudnicki M.D., (1999) Behavior of terrestrial dissolved organic matter at the continent-ocean boundary from high-resolution distributions, Geochim. Cosmochim. Acta (accepted).

Wilson C., Klinkhammer G.P. and Chin C.S., 1999, Hydrography within the Central and East Basins of the Bransfield Strait, Antarctica, J. Phys. Ocean., 29, 465-479. 